\title{
Consensus
}

Volume 31

Issue 1 Preaching the Gospel in Canada in the 21st

Article 18

Century

$5-1-2006$

\section{The imaginative world of the Reformation}

David Schnasa Jacobsen

Follow this and additional works at: http://scholars.wlu.ca/consensus

\section{Recommended Citation}

Jacobsen, David Schnasa (2006) "The imaginative world of the Reformation ," Consensus: Vol. 31 : Iss. 1 , Article 18.

Available at: http://scholars.wlu.ca/consensus/vol31/iss1/18

This Book Reviews is brought to you for free and open access by Scholars Commons @ Laurier. It has been accepted for inclusion in Consensus by an authorized editor of Scholars Commons@ Laurier. For more information, please contact scholarscommons@wlu.ca. 
visually-oriented culture. She asks whether the present-day spiritual hunger in North America relates to a lack of religious images capable of inspiring imitation, and whether contemporary Christians have a range of images that can effectively remind them of their calling. Cook provides an outline of the way in which art has historically reflected the major theological concerns of its time, and notes that the present age seems bereft of broadly-accepted art forms that shape belief and behavior. He then identifies the challenge facing contemporary Christian artists: they must find ways of speaking through the arts in an age of radical individuality, when there are varying and often conflicting trends in theological thinking.

Interpreting Christian Art is well illustrated, with eighty-two black and white reproductions of works under discussion. While there is no bibliography, each chapter is extensively documented. The page layout, which places notes in the side margins, makes crossreferencing easy to follow.

Mikeal C. Parsons is a professor of religion at Baylor University, and is the author of The Departure of Jesus in Luke-Acts and coeditor of Rethinking the Unity of Luke and Acts. Heidi J. Hornik is an associate professor of art history at Baylor University, and the coeditor, with Mikeal Parsons, of Illuminating Luke: The Infancy Narrative in Italian Renaissance Painting.

Diane E. Peters

Wilfrid Laurier University / Waterloo Lutheran Seminary

\section{The Imaginative World of the Reformation \\ Peter Matheson \\ Minneapolis: Augsburg Fortress, 2001 \\ 168 pages, \$20 Paperback}

This book by Peter Matheson, Principal of the Theological Hall of the Uniting Church in Melbourne (Australia), breaks new ground in the area of Reformation studies in Germany. Whereas so many of the important works in the field have split between a kind of disembodied "history of ideas" approach and a detailed, materialist "social history" approach, Matheson explores the ways in which 
the Reformation impacted people and their imaginations. He looks at root metaphors in the writing of Reformation figures, and considers artwork from the time, including woodcuts and paintings. Matheson does not bypass the ideational world of doctrine nor does he abandon the concrete world of social history, but he does not allow these traditional beginning points to define his investigation.

The book begins with a question: What could have impelled people to leave the visual, iconic, tangibly sacramental world of Medieval Roman Catholicism for a stark Protestantism enamoured only of the Word of God? It would be too simple to imagine people coming out of this lavish world of the Mass into the harsh light of Protestant iconoclasm. There must have been something about the content, shape, form, and feel of Protestant speaking, preaching, writing, art, etc., that made it a compelling imaginative world to dwell in. At the same time, Matheson takes pains to outline other aspects of the contemporary culture that would have provided allies for the emerging imaginative world of the German Reformation, especially the rise of rural and urban utopias.

He also acknowledges the demonic aspects of these developments and their dynamics. While the spoken Word, the written word, and art are all capable of naming and illustrating the dreams which reflect Reformation impulses about grace, Word, and freedom, they are equally capable of producing apocalyptic nightmares, too. In this way, Matheson reminds the reader of the tragic fallenness of even the imaginative world of the Reformation.

The book concludes with two chapters that bring the reader back to the received world. The first of these explores the impact of the imaginative world of the Reformation upon the contours of daily life, here chiefly through the letters, life, and work of an evangelically-inclined, sixteenth-century Bavarian noblewoman, Argula von Grumbach. By investigating her own words and deeds from the perspective of the imaginative world of the Reformation, Matheson illustrates her daily life and its compromises. The final chapter then allows readers to consider how this imaginative world might inform spirituality today. Here is something still quite habitable for our disenchanted, modern imaginations: a kind of gritty spirituality that looks for hints of grace in the muck of life but 
refuses to wallow in a sentimentality that acts as if the world were still enchanted.

As a teacher of preaching, I find it refreshing to find a work by a historian that takes seriously the media by which we hear and appropriate the Reformation Gospel of God's grace. While Matheson's book occasionally tends to the romantic (as is the wont of books about imagination), he often just as quickly checks himself and properly reminds readers of the contradictions and ironies that make history what it is. I recommend the book highly for those who wish to consider in a new way not just what but how the Reformation might be meaningful for us today.

David Schnasa Jacobsen

Waterloo Lutheran Seminary

\section{Perspectives Old and New on Paul: The "Lutheran" Paul and His Critics \\ Stephen Westerholm \\ Grand Rapids, Michigan: Eerdmans, 2004 \\ 508 pages, $\$ 42$ Paperback}

I recently had the pleasure of teaching a one-term course on Paul and his letters, for which Westerholm's fine work on how Paul has been interpreted for the last two thousand years proved to be a superb resource. I recommend it to all who have interests in the historical Paul of the first century, but especially those who seek to understand the impact of the apostle to the Gentiles in the subsequent history of the Christian church, in the scholarly world, and in the recent explosion of healthy Jewish-Christian dialogue.

To be sure, this is not a New Testament text as such; rather it falls more comfortably into the realm of the history of ideas. After all, the book begins with an analysis of how Augustine understood and used Paul. Nonetheless, it remains a valuable work for New Testament scholars in at least two respects.

First, in the last extensive section of his work ("Part III: The Historical and the 'Lutheran' Paul"), Westerholm provides an indepth analysis of the Pauline corpus in relation to the very 